\title{
常温下間歇的肝門部遮断による肝切除術に関する
}

\author{
実験的・臨床的研究 \\ 順天堂大学医学部第 2 外科（指導 : 杉浦光雄教授） \\ 奥山耕 一

\section{EXPERIMENTAL AND CLINICAL STUDIES ON HEPATIC RESECTION BY INTERMITTENT INTERCEPTION OF HEPATIC HILUS UNDER NORMOTHERMIC STATE}

\section{Kouichi OKUYAMA}

The Second Department of Surgery, Juntendo University School of Medicine

(Director : Prof. Mituo Sugiura)

\begin{abstract}
硬変肝切除に括ける出血量減少の目的で，5分間隔の常温下間歇的肝門部遮断を実験的・臨床的に 施行，検討した，実験的には，雑種成犬40頭を用い，20分，40分間の肝門部遮断をそれぞれ施行し， 遮断後の肝・空腸・下行結腸の組織血流量を経時的に測定検討した，遮断解除後の各臟器の組織血流 量は, 間歇遮断群に比べ, 連続遮断群で有意に減少した。肝組織血流量は間歇遮断群で遮断前値と比 べ有意の減少は示さなかった。臨床的には肝切除62例中, 硬变肝切除28例に間歇遮断を施行し, 術中 出血量は遮断群で有意に減少し，術後肝機能の推移は非遮断群との間に有意差を認めなかった，以上 より，本法は硬变肝切除時の出血制御に有用であると思われた。
\end{abstract}

象引用語：Pringle 法, 間歇的肝門部遮断, 肝切除, 肝硬变併存肝癌, 水素クリフランス法

\section{I. 粕 言}

画像診断, 肝硬变治療の進歩により, 原発性肝細胞 癌 (以下 HCC と略す) に対して積極的に肝切除が行わ れるようになったが, 高度肝硬変併存例が増えており, 肝機能予備力からの制約で亜区域以下の切除症例が増 加している.これらに対しては, controlled method" や系統的な脈管系処理を行う肝切除2が困難なことが 多く，しばしば術中大量出血を起こすこともあり，高 度肝障害例では，肝不全の誘起因子ともなっている。 肝切離時の出血制御の方法として, controlled method のほかに特殊な鉬子を用いた肝圧迫法3), Pringle 法4) などが行われている. Pringle 法4)は1908年, 肝外傷の 出血に対し, Pringle が初めて応用した方法で, 肝十二 指腸間膜を用手で肝流入血行を遮断する方法であり， 現在でる肝胆道系の不虑の出血に対して，しばしが臨 床的に応用されているが, 硬変肝切除に本法が応用さ

$\lessdot 1986$ 年11月 12 受理 $>$ 別刷請求先：奥山 耕一 T113 文京区本郷 2-1-1 順天堂大学医学部第 2 外科
れた報告5)6) は少なく，著者は硬変肝切除に際し，Pringle 法を応用し, 5 分遮断 5 分間放を繰り返す常温下 間歇的肝門部遮断を行い, 実験的, 臨床的に肝および 門脈系の血行動態の恋動, 肝機能におよぼす影響につ き検討を行った。

\section{II. 実験的研究}

1. 実験方法

A. 実験モデル

体重10 15kg の雑種成犬40頭を用い, Pentobarbital sodium $25 \mathrm{mg} / \mathrm{kg}$ による静脈麻酔下で気管内插 管を行い，Respirator (Aika, R-60)での調節呼吸 (15 $\mathrm{ml} / \mathrm{kg} /$ 回, 20 回/分)を行った. 腹部正中切開を加兄, 肝門部以外の肝流入血行遮断を施行し，肝十二指腸間 膜を血管鉗子で把持し，常温下肝門部遮断を行った。 また，大動脈，門脈へそれぞれカテーテルを挿入し， ポリグラフ（日本光電社 RM-6300）にて動静圧, 門脈 圧の連続モニターおよび記録を行った。また，水素ク リアランス式組織血流計（ニニークメディカル社 PHG-201）を用い, 肝, 空腸および下行結腸の組織血 
図 1 実験モデル

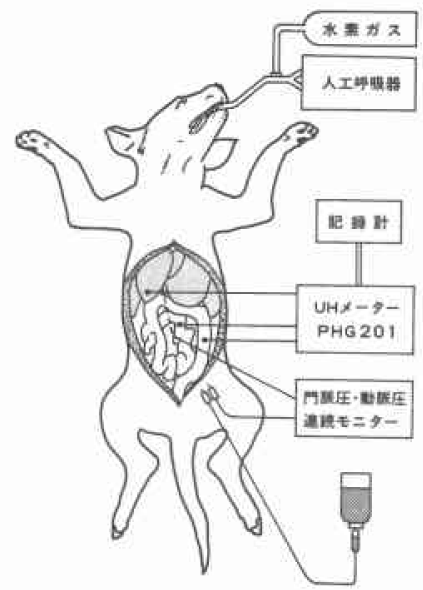

流量を測定した（図 1 ）。

B. 遮断手技

以下のごとく 10 頭ずつ 4 群について実験を行った.

1） 20 分連続遮断群：肝門部遮断を20分間施行した 後, 解除した.

2) 20 分間歇遮断群：5 分間遮断, 5 分間開放の操作 を4回繰り返し，総遮断時間を20分とした。

3） 40 分連続遮断群：20分持続遮断群と同様な操作 で遮断を40分間施行した。

4） 40 分間歇遮断群：20分間歇遮断群之同様な操作 で 5 分間の遮断・開放を 8 回繰り返し, 総遮断時間を 40分とした。

C. 测定方法

1) 組織血流量の測定

肝内側右葉被膜下 $1 \mathrm{~cm}$, 空腸および下行結腸の腸間 膜付着部対側の粘膜下組織にそれぞれ刺入した特殊白 金電極より，水素ガスクリアランス法7)8)を用い，遮断 前, 遮断解除後 $5,20,40,60$ 分の組織血流量を測定 した.

2）門脈圧, 動脈圧の測定

門脈, 大動脈に留置したカテーテルにより連続モ二 ターを行い, 遮断前60分より遮断解除後60分をでの圧 変動を連続的に記録した。

\section{2. 実験成績}

A. 組織血流量の変動

1) 肝組織血流量の变動

20分間歇遮断群では, 遮断施行前は, $93.2 \pm 23.6 \mathrm{ml} /$ $\mathrm{min} / 100 \mathrm{~g}$ であった。遮断前値を 100 とすると, 遮断解 除後 5 分 $87.6 \pm 21.6 \%, 60$ 分 $124.4 \pm 18.7 \%$ であり, 遮
圀 2 肝門部遮断による肝組織血流量の変動（実験犬 各群 $\mathrm{n}=10$ )

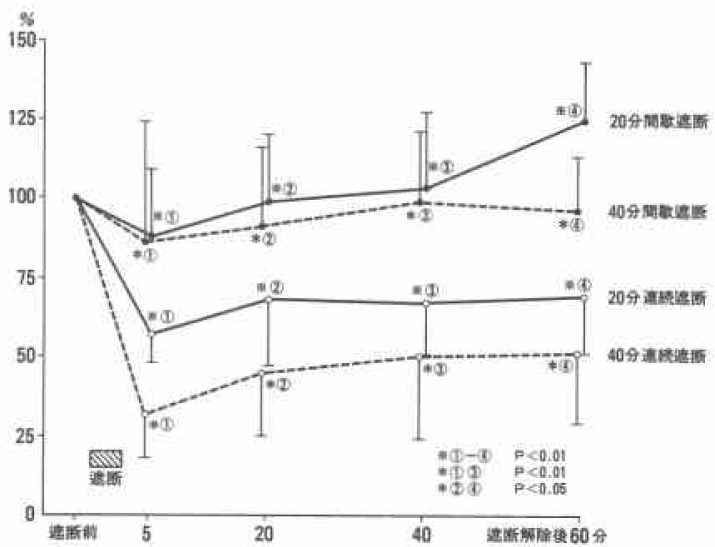

断解除後 5 分で最低值を示したが，遮断前と比較し， 遮断解除後60分まで有意差を認めなかった，20分連続

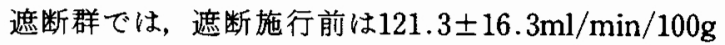
であり，遮断前值を 100 とすると，遮断解除後 5 分 $57.3 \pm 9.6 \%, 60$ 分 $69.0 \pm 18.0 \%$ であり, 遮断前と比較 し，遮断解除後60分まで有意 $(\mathrm{p}<0.01)$ に減少した。 また，20分間歇遮断群は20分連続遮断群と比較し，遮 断解除後60分まで有意 $(\mathrm{p}<0.01)$ の高值を示した. 40 分間歇遮断群では, 遮断施行前は, $105.0 \pm 20.4 \mathrm{ml} /$ $\mathrm{min} / 100 \mathrm{~g}$ であり, 遮断前值を 100 とすると, 遮断解除 後 5 分 $85.9 \pm 33.7 \%, 60$ 分 $96.0 \pm 17.3 \%$ あり，遮断 前と比較し，遮断解除後60分まで有意差を認めなかっ た. 40 分連続遮断群では，遮断施行前は，116.8土30.0 $\mathrm{ml} / \mathrm{min} / 100 \mathrm{~g}$ であり, 遮断前值る100とすると, 遮断解 除後 5 分 $31.5 \pm 13.1 \%, 60$ 分 $50.8 \pm 21.5 \%$ あ゙り，遮 断前と比較し, 遮断解除後60分まで有意 $(\mathrm{p}<0.05)$ の 減少を示した。また，40分間歇遮断群は40分連続遮断 群と比較し, 遮断解除後60分まで有意 $(\mathrm{p}<0.05)$ の高 值を示した（図 2).

2）空腸組織血流量の変動

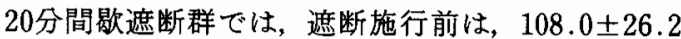
$\mathrm{ml} / \mathrm{min} / 100 \mathrm{~g}$ であった。遮断前值を 100 とすると, 遮断 解除後 5 分 $57.9 \pm 16.4 \%$ ，60分 $72.6 \pm 15.9 \%$ あり， 遮断前之比較し，遮断解除後60分まで有意 $(p<0.01)$ の減少を示した，20分連続遮断群では，遮断施行前は， $136.1 \pm 27.5 \mathrm{ml} / \mathrm{min} / 100 \mathrm{~g}$ であり, 遮断前值を 100 とす ると，遮断解除後 5 分 $29.0 \pm 2.5 \%, 60$ 分 $54.7 \pm 13.6 \%$ であり, 遮断前と比較し遮断解除後 60 分まで有意 $(\mathrm{p}<$ 0.01）の減少を示した。また，20分間歇遮断群は20分 
図 3 肝門部遮断による空腸組織血流量の変動（実験 犬 各群 $\mathrm{n}=10$ )

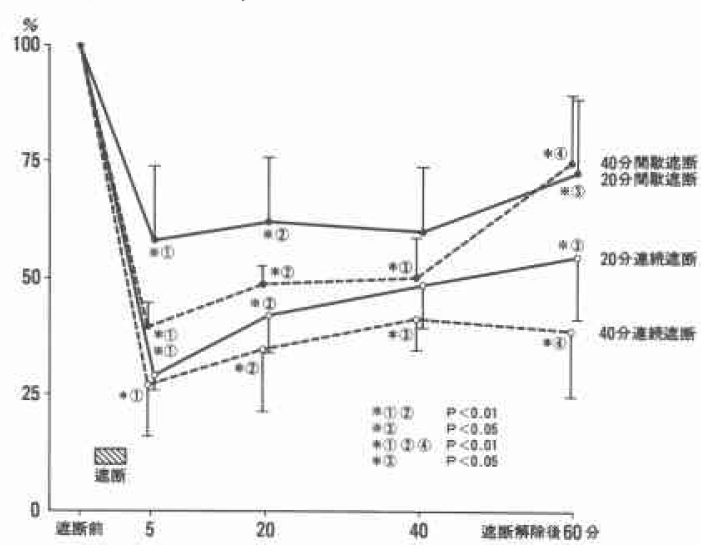

連続遮断群と比較し, 遮断解除後 5 分, 20 分, 60 分で 有意 $(\mathrm{p}<0.05)$ 高值を示した. 40分間歇遮断群では, 遮断施行前は, $99.7 \pm 18.0 \mathrm{ml} / \mathrm{min} / 100 \mathrm{~g}$ であり, 遮断 前値を 100 とすると，遮断解除後 5 分 $39.5 \pm 5.4 \%, 40$ 分 $50.2 \pm 8.7 \%, 60$ 分 $74.7 \pm 14.4 \%$ であり, 遮断前之比 較し, 遮断解除後 40 分まで有意 $(\mathrm{p}<0.01)$ の減少を示 した. 40 分連続遮断群では, 遮断施行前は, $123.8 \pm 26.8$ $\mathrm{ml} / \mathrm{min} / 100 \mathrm{~g}$ であり, 遮断前値を 100 とすると, 遮断解 除後 5 分 $27.1 \pm 11.1 \%, 60$ 分 $38.7 \pm 13.6 \%$ であり，遮 断前と比較し遮断解除後60分まで有意 $(\mathrm{p}<0.01)$ の減 少を示した。また，40分間歇遮断群は40分連続遮断群 と比較し, 遮断解除後60分まで有意 $(\mathrm{p}<0.05)$ の高值 を示した（図3）.

3）下行結腸組織血流量の変動

20 分間歇遮断群では, 遮断施行前は, $106.7 \pm 15.5$ $\mathrm{ml} / \mathrm{min} / 100 \mathrm{~g}$ であった. 遮断前値を100とすると, 遮断 解除後 5 分 $73.6 \pm 32.9 \% ， 60$ 分 $93.4 \pm 34.5 \%$ あ゙り， 遮断前と比較し, 遮断解除後 60 分まで有意差は認めな かった. 20 分連続遮断群では, 遮断施行前は, 128.3土 $29.2 \mathrm{ml} / \mathrm{min} / 100 \mathrm{~g}$ であり, 遮断前值を 100 とすると, 遮 断解除後 5 分 $45.8 \pm 4.4 \%, 60$ 分 $67.3 \pm 16.6 \%$ であり, 遮断前と比較し, 遮断解除後60分まで有意 $(\mathrm{p}<0.01)$ の減少を示した。 また，20分間歇遮断群は20分連続遮 断群と比較し, 遮断解除後60分まで有意 $(\mathrm{p}<0.05)$ の 高値を示した。 40 分間歇遮断群では, 遮断施行前は, $129.4 \pm 28.6 \mathrm{ml} / \mathrm{min} / 100 \mathrm{~g}$ であり, 遮断前值を 100 とす ると, 遮断解除後 5 分 $67.6 \pm 24.8 \%, 60$ 分 $79.7 \pm 10.8 \%$ であり, 遮断前と比較し, 遮断解除後60分まで有意差 を認めなかった. 40 分連続遮断群では, 遮断施行前は, $111.3 \pm 22.3 \mathrm{ml} / \mathrm{min} / 100 \mathrm{~g}$ であり, 遮断前值を 100 とす
図 4 肝門部遮断による下行結腸組織血流量の変動 （実験犬 各群 $\mathrm{n}=10$ ）

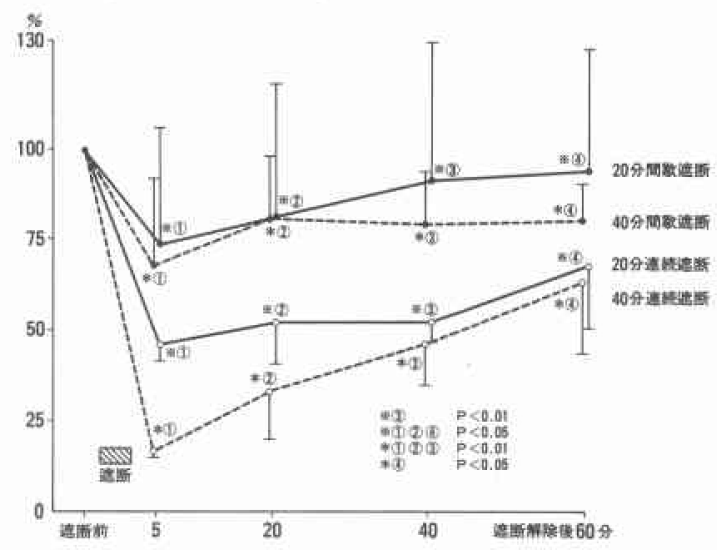

ると, 遮断解除後 5 分 $16.8 \pm 0.2 \%, 60$ 分 $62.9 \pm 19.3 \%$ であり, 遮断前と比較し, 遮断解除後 60 分まで有意 （p<0.01）の減少を示した。交た，40分間歇遮断群は 40 分連続遮断群と比較し, 遮断解除後 60 分まで有意 $(\mathrm{p}<0.05)$ の高値を示した（図 4 ).

B. 門脈圧, 平均血圧の变動

20分連続遮断群において, 遮断前の門脈圧は7 73 $\mathrm{mmHg}$, 平均血圧は $143 \pm 13 \mathrm{mmHg}$ であった。遮断施 行直後より門脈圧は, $59 \pm 8 \mathrm{mmHg}$ で急峻に有意 $(\mathrm{p}<0.01)$ の上昇を示し, 平均血圧は, $71 \pm 11 \mathrm{mmHg}$ まで徐々に有意 $(\mathrm{p}<0.01)$ の低下を示した。遮断解除 後は, 門脈圧 $7 \pm 3 \mathrm{mmHg}$, 平均血圧厈 $89 \pm 14 \mathrm{mmHg}$ と 速やかに注汇遮断前值へと回復し, 遮断前後の門脈圧 および平均血圧に有意差は認めなかった，20分間歇遮 断群に扮いては, 門脈圧は, 遮断前 $4 \pm 1 \mathrm{mmHg}$, 第 1 回 遮断 $62 \pm 8 \mathrm{mmHg}$, 第 4 回遮断 $58 \pm 9 \mathrm{mmHg}$, 遮断終了 後 $4 \pm 1 \mathrm{mmHg}$ であり, 平均血圧は, 遮断前 $97 \pm 20$ $\mathrm{mmHg}$, 第 1 回遮断 $72 \pm 28 \mathrm{mmHg}$, 第 4 回遮断 $64 \pm 28$ $\mathrm{mmHg}$, 遮断終了後 $90 \pm 28 \mathrm{mmHg}$ であった。遮断時お よび開放時の門脈圧, 平均血圧の变動は, 20 分連続遮 断群と同様であり, 遮断前後の門脈圧, 平均血圧に有 意差は認めなかった（図 5).

40 分連続遮断群に扣いて, 遮断前の門脈圧は $9 \pm 3$ $\mathrm{mmHg}$, 平均血圧は $130 \pm 9 \mathrm{mmHg}$ であった。遮断施行 直後より門脈圧は, 最高 $87 \pm 8 \mathrm{mmHg}$ まで有意 $(\mathrm{p}<$ 0.01 ) に上昇し, 平均血圧は, 最低 $49 \pm 8 \mathrm{mmHg}$ 索有 意 $(\mathrm{p}<0.01)$ に低下し, 20 分連続遮断と同様の変動で あった，遮断解除後に括いては，門脈王 $13 \pm 2 \mathrm{mmHg}$, 平均血厈は, $81 \pm 16 \mathrm{mmHg}$ であり，遮断前値と比較し， 門脈圧は有意 $(p<0.01)$ の上昇, 平均血圧は有意 $(p<$ 
図 520 分遮断による門脈圧と平均血圧の変動（実験

犬 連続遮断群 $\mathrm{n}=6$, 間歇遮断群 $\mathrm{n}=7$ )
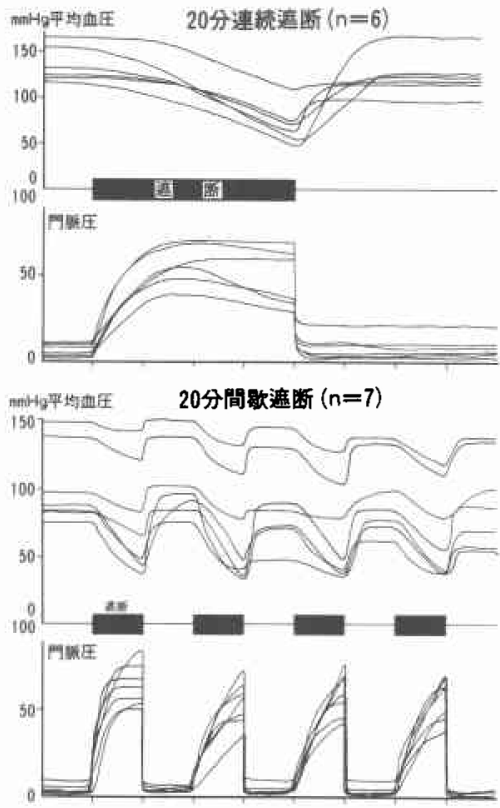

図 640 分遮断による門脈圧之平均血王の変動（実䮄 犬 各群 $\mathrm{n}=7$ )
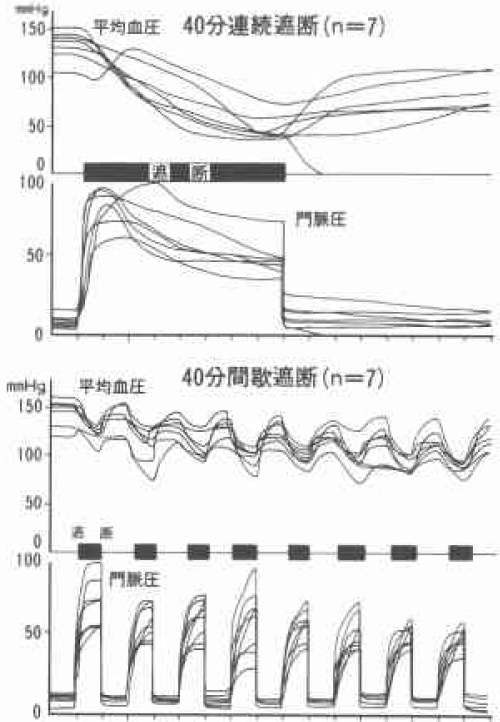

0.01）の低下を示した。 40分間歇遮断群においては, 門脈圧は, 遮断前 $9 \pm 1 \mathrm{mmHg}$, 第 1 回遮断 $65 \pm 10$ $\mathrm{mmHg}$, 第 8 回遮断 $50 \pm 4 \mathrm{mmHg}$, 遮断終了後 $9 \pm 2$ $\mathrm{mmHg}$ であり, 平均血圧は, 遮断前 $140 \pm 14 \mathrm{mmHg}$, 第 1 回遮断 $118 \pm 11 \mathrm{mmHg}$, 第 8 回遮断 $85 \pm 8 \mathrm{mmHg}$, 遮
断終了後 $112 \pm 10 \mathrm{mmHg}$ であり, 遮断終了後の平均血 王は遮断前値と比較し, 有意 $(\mathrm{p}<0.01)$ の低下を示し た（図 6 ).

\section{III. 臨床的研究}

1. 研究対象ならびに方法

A. 手術方法

開腹後, 胆襄摘出, 病巣側の肝葴を授動脱転後, 術 中超音波検查を行 5. 肝切離前に上腸間膜静脈の分枝 よりカニュレーションを行い, 術中門脈造影および門 脈圧の経時的測定を行う、次いで，肝門部脈管の剥離 露出は行わず，肝十二指腸間膜全体を Fogarty 鉗子で 把持し, Pringle 法による肝門部遮断を行い, 肝切離を 開始する. 遮断手技は，5分間の遮断と 5 分間の開放 を肝切離終了まで症例により数回繰り返す。肝切離操 作は, clamping \& division 法で行い，露出した肝内 脈管系を遮断開放時に4-0Ticron ®にて結禁止血を行 万。な拉，門脈大静脈系バイパスは置いていない.

\section{B. 対象}

1979年 9 月より，1986年 8 月までに教室で行った肝 切除術62例を対象とした(表 1 ). 平均年齢は55.7歳で あり, HCC は37例であった。このうち肝硬変併存が31 例 $(83.8 \%)$ を占め, 同時に食道静脈瘤合併が11例,

経胸食道離断術 (杉浦法) ${ }^{9}$ 施行後の経過観察中に $\mathrm{HCC}$ が発見された症例が 6 例であり, 肝硬変併存症例 の54.8\%を占めた。肝切除症例62例を間歇的肝門部遮 断の有無および, 非腫瘍部の肝硬変の有無により以下

表 1 肝切除症例

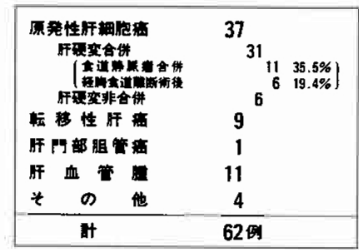

表 2 肝切除術式

\begin{tabular}{|c|c|c|c|c|c|c|}
\hline \multirow{2}{*}{ 群 } & \multicolumn{4}{|c|}{ 切绦笽囲 $(\mathrm{Hr})$} & \multirow{2}{*}{ 付加手政 } & \multirow[b]{2}{*}{ 针 } \\
\hline & 0 & s & 1 & 2 & & \\
\hline 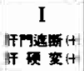 & 11 & 8 & 3 & 6 & 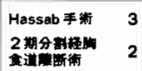 & 28 \\
\hline 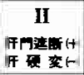 & 5 & 2 & 6 & 11 & 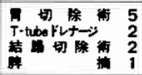 & 24 \\
\hline 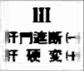 & 3 & 0 & 1 & 1 & Hassab 手涌 & 5 \\
\hline 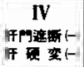 & 0 & 0 & 3 & 2 & 2 & 5 \\
\hline
\end{tabular}


のごとく 4 群に分類した.

$\mathrm{I}$ 群: 遮断 $(+)$ 肝硬変 $(+) 28$ 例

II群：遮断 $(+)$ 肝硬変 $(-) 24$ 例

III群：遮断 $(-)$ 肝硬変 $(+) 5$ 例

IV群：遮断 $(-)$ 肝硬変 $(-) 5$ 例

肝切除術式の内訳は, 表 2 に示寸. 肝切除術式の記 載は原発性肝癌取扱い規約 ${ }^{10)}$ に準じた。I群では, 表に 示したごとく，亜区域切除以下が大半を占めており，

II群では，区域切除以上が大半を占めている，III群で は, 部分切除が過半数であり, IV群では, 全例区域切 除以上である。

C. 検查測定項目

1）総遮断時間之術中出血量

I. II群において, 肝切離時に施行した間歇的肝門部 遮断の遮断時間を計測し, その総和を総遮断時間とし た. また, 術中出血量は付加手術を施行した症例を除 外した。

\section{2）術後肝機能の変動}

血液生化学は, 術前, 術後第 $1,3,5,7,14,21$, 28 病日まで計 8 回, 測定した. 測定項目は, 血清 GOT, GPT, LDH, ヘパプラスチンテスト (HPT), 総ビリル ビン（T-Bil）であり, 肝硬変例の I・III群間, 非肝硬 変例のII・IV群間で比較検討した。また，I群を総遮 断時間15分未満（以下 I（15>）群之略す）と総遮断

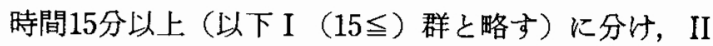

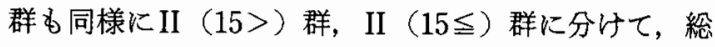
遮断時間の差に括いても比較検討した。

3）術中門脈圧, 動脈圧の変動

術中, 橈骨動脈および上腸間膜静脈分枝にそれぞれ カニュレーションを施行し, 肝流入血行遮断前後にお いて, 経時的に門脈圧, 急脈圧の变動を記録した。

\section{4) 病理組織学的検討}

I 群において, 肝切離前に病巣側の非腫瘍部より肝 生検を行い, 遮断施行後の非腫瘍部の病理所見と比較 検討した。

2. 臨床成績

1) 総遮断時間之術中出血量

総遮断時間は I・II群間に有意差を認めなかった。 術中出血量は, 肝硬変例の I ・ III群間, 非肝硬変例の II・IV群間において, 遮断施行の I 群, II 群がともに 有意（p<0.05）の低值を示した（表 3 ）.

2) 術後肝機能の変動

a) GOT の変動

I $(15>)$ 群において, 第 1 病日 $276 \pm 105 \mathrm{IU} / l$ と最
表 3 総遮断時間と術中出血量

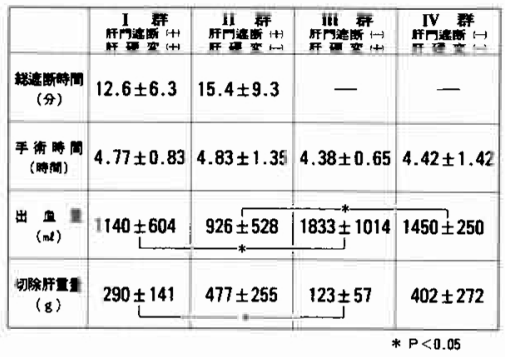

図 7 術後肝機能の变動 (GOT)

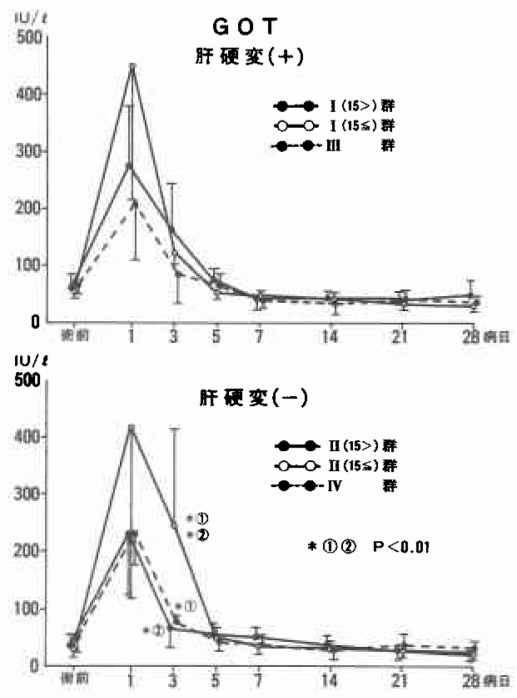

高値を示し，第 3 病日まで有意 $(\mathbf{p}<0.01)$ の高值を示

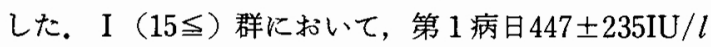
と, I (15>) 群と同様の変動であり, 第 3 病日まで 有意 $(p<0.01)$ の高值を示した. III群では, 第 1 病日 $210 \pm 100 \mathrm{IU} / l$ と, 第 1 病日で有意 $(\mathrm{p}<0.01)$ の高値を 示した. II (15〉) 群では, 第 1 病日 $232 \pm 108 \mathrm{IU} / l$ と 最高値を示し，第 7 病日まで有意 $(\mathrm{p}<0.05)$ の高値を 示した. II (15ミ) 群では, 第 1 病日 $418 \pm 299 I U / l$, で あり, II (15>) 群と同様の変動であり, 第 5 病日ま で有意 $(\mathrm{p}<0.01)$ の高值を示した。IV群では, 第 1 病 日 $229 \pm 53 \mathrm{IU} / l$ と, 同様の変動であり, 第 1 病日に拈い て有意 $(\mathrm{p}<0.01)$ の高值を示した。肝硬変合併の I

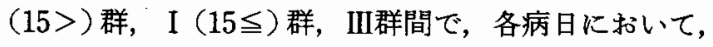
有意差を認めず, 肝硬変非合併の II (15>)群, II (15 )

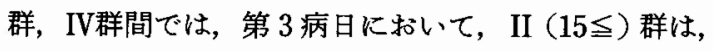
II $(15>)$ 群, IV群と比較し, 有意 $(\mathrm{p}<0.01)$ の高値 を示した (図 7). 
図 8 術後肝機能の变動 (HPT)

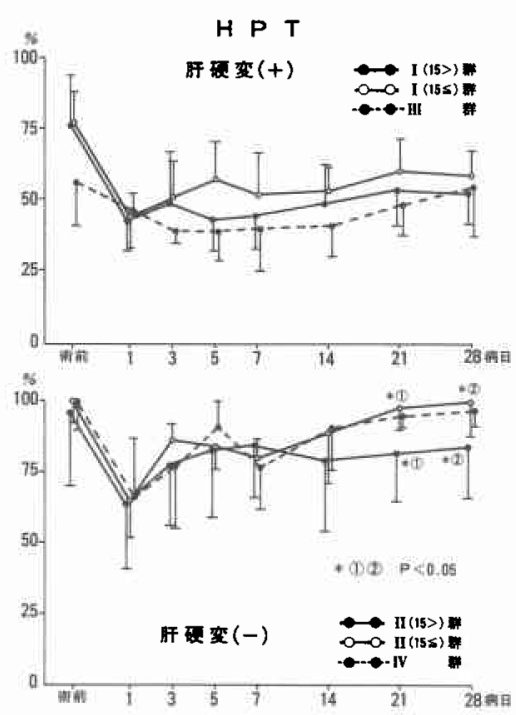

b) GPT, LDH の変動

GPT, LDH ともにGOT と同様の変動であり, 肝硬

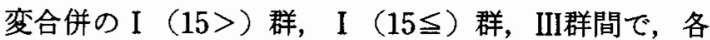
病日において，有意差を認めず，肝硬変非合併の II

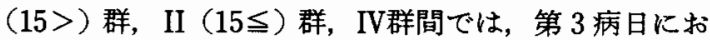

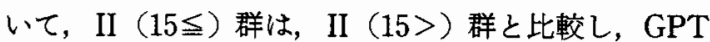
が有意 $(\mathrm{p}<0.01)$ の高值を示した。

c) HPT の変動

I（15>）群において，第 1 病日 $42.8 \pm 10.9 \%$, 第 28 病日 $53.2 \pm 11.4 \%$ あ゙り，第 1 病日以降，有意 $(\mathrm{p}<$

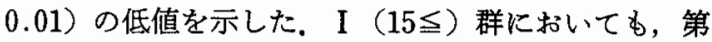
1 病日 $44.0 \pm 10.9 \%$, 第 28 病日 $58.8 \pm 9.3 \%$, 同様の 変動であり, 第 1 病日以降, 有意 $(\mathrm{p}<0.05)$ の低値を 示した. III群では, 第 3 病日 $38.7 \pm 3.6 \%$, 有意 $(\mathrm{p}<$ 0.05）の低值を示し，各群間で，各病日に扣いて有意 差を認めなかった。 II (15>)群では，第 1 病日64.0土

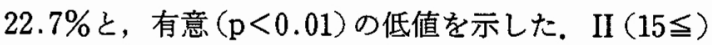
群では，第 1 病日 $65.2 \pm 12.9 \%$ ，第 7 病日 $79.8 \pm 6.7 \%$ であり，第 7 病日まで有意 $(\mathrm{p}<0.01)$ の低值を示した。

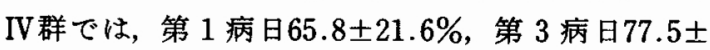
$22.6 \%$ ，第 7 病日 $76.5 \pm 14.2 \%$ あ゙り，第 5 病日を除 く第 7 病日まで有意 $(\mathrm{p}<0.05)$ の低值を示した。各群

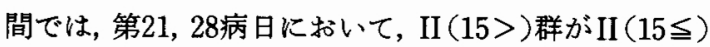
群と比較し, 有意 $(\mathrm{p}<0.05)$ に高値を示した（図 8 ).

d) $\mathrm{T} \cdot \mathrm{Bil}$ の変動

I（15>）群において，第 3 病日 $2.33 \pm 1.10 \mathrm{mg} / \mathrm{dl}$, 第 5 病日 $2.33 \pm 0.91 \mathrm{mg} / \mathrm{dl}$, であり, 第 3,5 病日を最
図 9 術後肝機能の変動 (T-Bil)
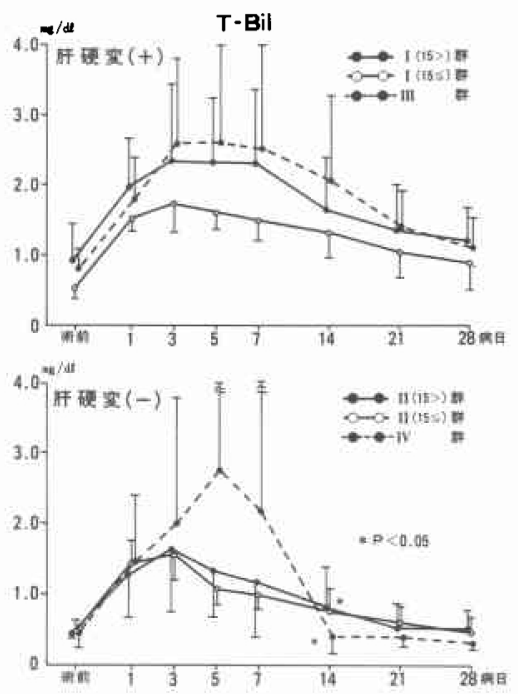

高値とし，第 1 病日より第21病日まで有意 $(\mathrm{p}<0.05)$

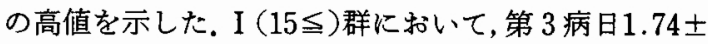
$0.41 \mathrm{mg} / \mathrm{dl}$ であり，第 3 病日を最高值とした同様の変 動であり，第 1 病日より第28病日まで有意 $(\mathrm{p}<0.01)$ の高值を示した。 III群では，第 3 病日 $2.58 \pm 1.21 \mathrm{mg} /$ $\mathrm{dl}$, 第 5 病日 $2.61 \pm 1.46 \mathrm{mg} / \mathrm{dl}$ と同様の変動であり, 第 3 , 5 病日で有意 $(\mathrm{p}<0.05)$ の高值を示し, 各群間に おいては，各病日において有意差を認めなかった，II (15>)群では，第 3 病日 $1.65 \pm 0.88 \mathrm{mg} / \mathrm{dl}$ であり，第 3 病日を最高値とし，第 1 病日より第14病日まで有意 $(\mathrm{p}<0.05)$ の高値を示した. II $(15 \leqq)$ 群では，第 3 病日 $1.56 \pm 0.36 \mathrm{mg} / \mathrm{dl}$ を最高值とし，第 1 病日より第 14病日まで有意 $(p<0.05)$ の高値を示した。 IV群では, 第 5 病日 $2.77 \pm 3.14 \mathrm{mg} / \mathrm{dl}$ を最高値とし, 第 5 病日ま で有意 $(\mathrm{p}<0.05)$ 高値を示した．各群間においては,

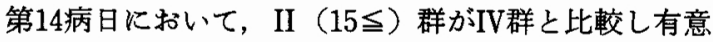
$(\mathrm{p}<0.05)$ の高値を示した（図 9).

3）術中門脈圧, 動脈圧の変動

I 群に抒いて, 門脈王は肝切離前 $256 \pm 39 \mathrm{mmH}_{2} \mathrm{O}$ ， 遮断時 $500 \pm 137 \mathrm{mmH}_{2} \mathrm{O}$, 肝切離後 $271 \pm 128 \mathrm{mmH}_{2} \mathrm{O}$ であり, 平均血王は肝切離前 $71 \pm 9 \mathrm{mmHg}$, 遮断時76土 $14 \mathrm{mmHg}$, 肝切離後 $72 \pm 13 \mathrm{mmHg}$ であった。 II群にお。 いて, 門脈圧は肝切離前 $123 \pm 43 \mathrm{mmH}_{2} \mathrm{O}$, 遮断時 $415 \pm$ $116 \mathrm{mmH}_{2} \mathrm{O}$, 肝切離後 $175 \pm 75 \mathrm{mmH}_{2} \mathrm{O}$ であり, 平均血 圧は肝切離前 $77 \pm 19 \mathrm{mmHg}$, 遮断時 $81 \pm 13 \mathrm{mmHg}$, 遮 断終了後 $83 \pm 16 \mathrm{mmHg}$ であった，門脈圧において，肝 切離前を100とすると，I 群において，門脈王は遮断時 
図10 間歇的肝門部遮断による門脈圧上昇率と平均血 圧の変動
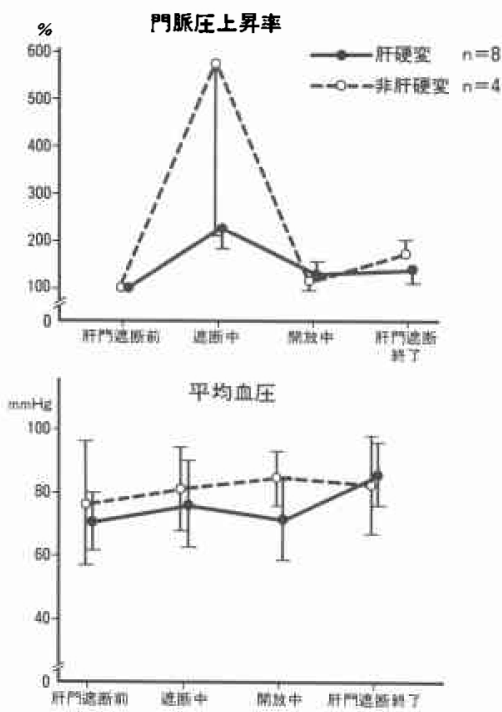

因11 間歇的肝門部遮断前後での病理組織所見の変化 （総遮断時間 28 分 18 秒，乙型肝硬变症例）

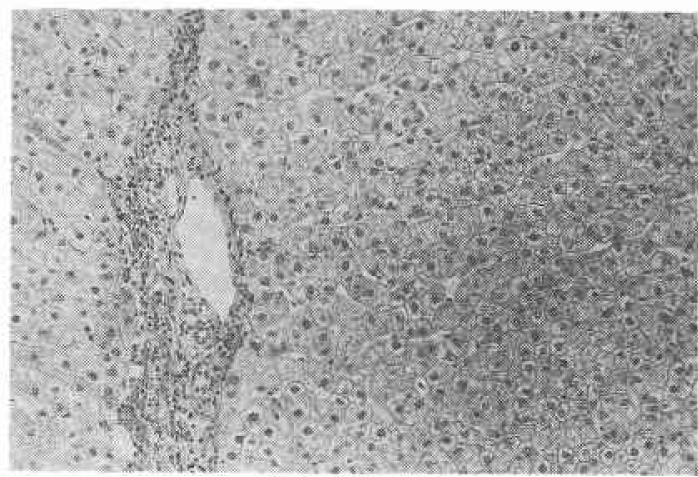

遮 断 前

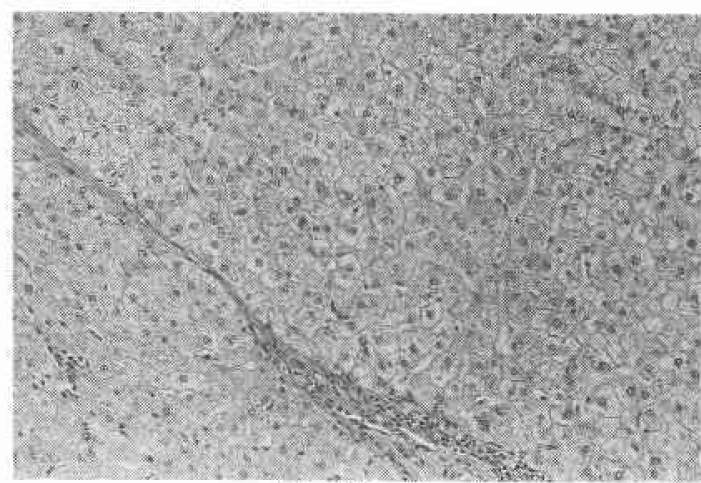

遮 断 後
$212 \pm 47 \%$, 遮断終了後 $138 \pm 24 \%$ であり, II 群に打い $\tau$, 門脈圧は遮断時 $580 \pm 368 \%$, 肝切離後 $170 \pm 31 \% て ゙$ あり，I群はII群と比較し，門脈圧上昇率が低い傾向 であった。また，平均血王は両群に招いて遮断前より 遮断終了後まで有意に変動を示さなかった（図10）。

4) 病理組織学的検討

I 群での非腫場部肝組織について, 好酸性变化, 空 胞変性, 肝細胞萎縮, 凝固壊死について遮断前, 遮断 時間15分未満・15分以上に扔いてそれぞれ比較検討し たところ，遮断の影響と思われる変化を認めなかった (図11).

\section{IV. 考 寨}

肝切除に際して, 術中大量出血は手術の妨げとなり， また高度肝硬変症例では, 術後肝不全のじゃっ起因子 となる. 肝切離時の出血を制御する目的で古くから 種々の方法が行われており，肝切除術の基本術式とし て Lotat-Jacobらの controlled method ${ }^{1}$ が代表的で あり, 肝葉切除以上の広範囲切除に施行されるが, 本 邦においては肝硬変併存例が多く, 広範囲肝切除は肝 機能予備力の面より，適応となる症例は限定される。 また, $\mathrm{Lin}^{3)}$ の考案した特殊肝荿鉬子を用いた肝圧迫法 があり，肝実質の薄い左葉の外側区域切除には有用で あるものの, 肝硬変例に扮いては, 肝の硬度も強く, 脈管の圧迫が十分とは言えず，出血制御が不十分であ ると思われる，肝硬変例では，系統的区域・亜区域切 除)または部分切除が選択されることが多く, 担癌区 域の門脈枝は肝切離時に肝内にて脈管処理を行われる ことになり, microwave coagulator, Cavitron ultrasonic surgical aspiration (以下CUSA と略す), LASERなどを応用した肝切除も行われている. CUSA や LASER は非硬変肝では良好な出血制御が 可能であるが, 肝硬変では, 必ずしも十分な出血制御 が可能とはいい難く, Microwave coagulator は, 肝 内の太い脈管の近傍は十分に凝固止血しえない点があ り,以上いずれの方法においても肝硬変例においては, 十分から確実な止血効果には限界があると思われる。 Pringle 法年は，1908年に Pringle が肝外傷の際の出血 制御に肝門部を用手で一時的に肝流入血行を遮断して 手術を行ったことを報告して以来, 本法は肝胆道系手 術の不慮の出血の際にしばしば応用されている. 実験 的には, Raffuci ら ${ }^{11}$, Goodall ら ${ }^{12}$ はイヌを用い，常 温下肝門部遮断の許容時間はほぼ20分としている。 た, 低体温麻酔 ${ }^{121313}$, 門脈体循環バイパス ${ }^{14) 15}$ などによ り遮断時間の延長が可能と報告されている．臨床的に 
は, Patchter ら ${ }^{16)}$ は, 肝外傷の手術に際し，30例に平 均30分の低体温下肝門部遮断を行い, Huguet ら ${ }^{17}$ は, 肝切除の際に24 65分間の遮断を行い，ヒトでの許容 時間は60分に近いと報告している。これら臨床例にお ける報告はいずれも非肝硬変症例であり, 肝硬变例に 対して肝門部遮断を行っている報告4)5 は現在まで泀 とんどみられていない。

Pringle 法は手技的に容易であり，迅速に施行でき， 肝臓のぞの部位においても確実な出血制御が可能であ るが, 肝細胞虚血による肝障害の増悪々閃脈系臟器の らっ血 (splanchnic pooling)の二点が本法の臨床応用 を困難にしている，教室では，この障害困子への対応 として, 間歇的に 5 分間の遮断・開放を繰り返す Pringle 变法を考案し, 硬变肝切除の定型的手技として用 いてきた. Pringle 法は全肝阻血であるため, 1 回の遮 断時間が可及的に短い方が良いのは当然のことであ り, 肝機能予備力の低下している肝硬変に対しては, とくに残存肝への影響を考慮し, 肝阻血による肝障害 の悪化を極力抑える必要があり, 肝切離操作との兼ね 合いで 5 分遮断・5 分開放と設定した。また，遮断開 放時に，肝切離操作が中断しないように，遮断時に露 出脈管をモスキート銝子で把持し，開放時に結禁する という手技の工夫を行った。著者の実験では, 空腸, 下行結腸に括いて，20分遮断，40分遮断ともに，間歇 遮断は連続遮断と比較し, 血流減少が少ないことから， 5 分間隔の間歇的遮断は血流の間歇的再開により, 腸 管のらっ血が連続遮断より軽減されるものと思われ る.臨床例においては, 肝門部遮断と同時に門脈流域 の静脈に軽度の怒張を認めるが，遮断開放と同時に速 やかに消退し, 遮断中, 門脈系臟器に認むべきうっ血, 浮腫, 出血斑は全く無かったことや, ヒトの場合はイ 又と異なり, 正常肝に㨟いて子微小な側副血行路が発 達しているとされておう，肝門部遮断の影響を受けに くく, 肝硬変症例ではさらに側副血行路が発達してい ることから門脈大循環系バイパスは，5分間隔の間歇 遮断の際には, とくに必要がないものと思われる。臨 床例での遮断による門脈圧の変動の結果からも肝硬変 例は遮断時の門脈圧上昇率が非肝硬変例より低く, 常 時, 門脈厈方進状態にある肝硬変では, 門脈系臓器は すでにうっ血状態にあり，遮断による急激な圧上昇に 対しても，側副血行路への血流の増加などにより，正 常肝よりも影響を受けにくいものと思われる。肝阻血 への影響に関して, 著者の実験結果から間歇遮断群で は, 40 分遮断においても, 遮断解除術 5 分での血流は
有意の減少が認められず, 他方, 連続遮断群において は, 20 分遮断に招いても遮断解除後60分まで有意な血 流減少を示した。遮断解除術の肝組織血流量が維持さ れることは, 遮断による肝細胞への低酸素状態の回復 といら点で, 有利であると思われる。 また，40分連続 遮断群において, 遮断解除後門脈圧が遮断前より有意 の上昇を来したことにより，間歇遮断群では 5 分ごと に肝への血流が再開することで連続遮断群より肝内の 微小血栓の形成など, 肝内での血流抵抗の原因となる 要因が軽度であると思われる。臨床例において, Huguet $ら^{17}$ は, 非硬変肝腫崲 9 例に肝門部遮断遮断 による肝切除を行い, 血清トランスアミナーゼ, 総ビ リルビンは切除肝重量と相関し, 遮断時間とは相関関 係はないと報告し, Nagasue ら $ら^{5)}$ は肝硬变合併症例の 肝切除に肝門部遮断を15例に用い, 術後肝機能の変動 は非遮断と有意差を認めなかったと報告している，著 者の検討においても，同様に血清 GOT，GPT，LDH， HPT, T-Bil の変化と遮断時間との間に相関関係を認 めず, また, 肝硬変群, 非肝硬变群ともに総遮断時間 15分未満の場合之 15 分以上の場合とで, 術後肝機能検 查所見に明らかな差を認めないことから，5 分間隔の 間歇遮断においては, 肝阻血の影響は少ないるのと思 われる。森ら ${ }^{18}$ は, 肝門部片葉遮断は術中出血量の減少 に有効であり, 遮断による術後肝機能の増悪を認めな かったと報告して和り，肝門部遮断による肝切除のひ とつの方法として有用と思われるが, controlled method と同様に肝門部で脈管の䟝離操作を行うた め, 肝十二指腸間膜に側副血行路の発達した症例では 術中出血量の増加を招く場合があり, 京対側葉にお よぶ腫瑒の場合，遮断を左右交互に行わなければなら ず，手技が複雑化することがある。また，畽湟側葉は 片葉とい壳ども連続遮断であるため, 高度肝硬变症例 においては阻血による肝機能障害を誘起する危ぐがあ るため可及的に遮断時間を短くするか, 間歇遮断を行 ら必要があると思われる。著者の 5 分間隔の間歇的肝 門部遮断では脈管の剶離操作は不要で, 手技がより容 易であり，危ぐする全肝阻血への影響や splanchnic poolingの影響は少なく応用範囲はより大きいと思わ れる。

Pringle 法を応用した 5 分間隔の常温下間歇的肝門 部遮断に上る肝切除術は確実北術中出血量の減少を図 ることが可能であり, 亜区域以下の切除または肝外脈 管の䟝離操作が困難な症例に対して最も適応があると 思われる。また, 連続遮断と比較し，肝硬変例におい 
ても splancnic pooling や肝阻血による術後肝機能一 の影響は少なく, 硬変併存肝癌に打ける肝切除に応用 しらると思われた。

\section{V. 結 語}

間歇的肝門部遮断による肝切除に対して遮断の肝・ 門脈系の組織血流におよぼす影響と肝機能におよぼす 影響とを検討し，以下の結論を得た。

1. 実験的研究

1）正常犬で20分および40分の間歇遮断・連続遮断を 行い, 肝・空腸・下行結腸で組織血流の変動を測定し, 20 分遮断, 40 分遮断々もに連続遮断は間歇遮断に比べ, 有意に組織血流量の減少を示した。

2）間歇遮断，連続遮断ともに，遮断時に門脈止は有 意に上异し，平均血圧は有意に低下した。また，遮断 前後において，40分遮断で遮断解除術に平均血圧は有 意に低下し，40分連続遮断群で門脈圧が有意に上昇し た.

\section{2. 臨床的研究}

1）術中出血量は遮断施行群が遮断非施行群之比較 し, 肝硬変・非肝硬変症例ともに有意に減少した。

2）術後第28病日まで経時的に血清 GOT, GPT, HPT, T-Bil を測定し, 肝硬变・非肝硬変例ともに, 遮 断・非遮断群間に明らかな差を認めなかった。

3）遮断による門脈圧の変動は, 肝硬変例で非肝硬変 例に比べ，門脈圧上昇率が低い傾向を認めた。

稿を終えるに臨み, 御指導·御校閲を賜った恩師杉浦光雄 教授に深謝の意を表すとともに, 本研究に終始, 御協力·御 鞭撻下さいました二川俊二助教授，児島邦明助手ならびに 本学第 1 病理学教室桑原紀之助教授, 第 2 外科学教室諸兄 に感謝の意を表します。

なお, 本論文要旨は第46回日本臨床外科医学会総会, 第26 回, 第28回日本消化器外科学会総会, 第20回日本肝䑏学会東 部会にて発表した。

\section{文献}

1) Lotat-Jacob JL, Robert JG: Hepatectomie doite reglee. Press Med 60:549-551，1952

2）幕内雅敏，長谷川博，山崎 晋：超音波を利用する 区域・亜区域切除術，日外会誌 $84: 913-917$, 1983

3) Lin TY: A simplified technique for hepatic resection. Ann Surg $180: 285-290,1974$

4) Pringle JH: Notes on arrest of hepatic hemor- rhage due to trauma. Ann Surg $48: 541-549$, 1908

5）児島邦明，奥山耕一，二川俊二ほか：肝門遮断によ る硬変合併肝癌切除術。順天堂医 $29: 506-513$, 1983

6) Nagasue $N$, Yukaya $H$, Suehiro $S$ et al: Tolerance of the cirrhotic liver to normothermic ischemia. Am J Surg $147: 772-775,1984$

7) Aukland K, Bower BF, Berliner RW: Measurement of local blood flow with hydrogen gas. Circ Res 14:164-187, 1963

8) Kety SS: The theory and applications of the exchange of inert gas at the lungs and tissues. Pharmacol Rev 3:1-40, 1951

9）杉浦光雄，市原荘六，野村 満法加：門脈圧充進症 の外科的治療一とくに東大第 2 外科法について 一。目医新報 $2410: 7-11,1970$

10）日本肝癌研究会編：臨床・病理. 原発性肝癌取扱い 規的。東京，金原出版，1983

11) Raffuci FL, Lewis JL, Wangensteen $\mathrm{OH}$ : Hypothermia in experimental hepatic surgery. Proc Soc Exp Biol Med 83 : 639-640, 1953

12) Goodall RGW, Hyndman WWB, Gurd FN : Studies on hypothermia in abdominal surgery. Arch Surg 75 : 1011-1019, 1957

13) Huggins CE, Carter EL: Partial hepatectomy employing differential hypothermia. Arch Surg $74: 189-202,1957$

14) Jolly PC, Foster JH: Hepatic inflow stasis. Surg $54: 45-55,1963$

15）加藤幸三：門脈体外循環施行下の肝流人血行遮断 に関する実験的研究。日外宝函 $35: 346-362$, 1966

16) Pachter hL, Spencer FC, Hofstetter SR et al: Experience with the finger fracture technique to achieve intrahepatic hemostasis in 75 patients with severe injuries of the liver. Ann Surg 197 : $771-778, \quad 1983$

17) Huguet $C$, Nordlinger $B$, Bloch $P$ : Tolerance of the human liver to prolonged normothermic ischemia. Arch Surg 113:1448-1451, 1978

18）森孝郎, 幕内雅敏, 小林縮純注：肝門部片葉 阻血法に捺ける血清 GPT 值, 血清 GOT 值, 血清 LDH 值, 血清 AL-P 值, ならびに総ビリルビン值 の変動に関する臨床的研究. 日外会誌 $86: 837$ $-845,1985$ 